\title{
Comparative Yeild and Oil Quality of Toxic and Non-Toxic Mexican Jatropha curcas Grown in the Same Agroclimatic Conditions
}

\author{
Khandual Sanghamitra $^{{ }^{*}}$, Ramirez Victorin Oramas ${ }^{2}$, Rout Nutan Prasad ${ }^{1}$ \\ ${ }^{1}$ Centro de Investigación y Asistencia en Tecnología y Diseño del Estado de Jalisco, A.C. Av. Normalistas \#800, Colinas de la \\ Normal, Guadalajara, Mexico; ${ }^{2}$ Colegio de Postgraduados-Campeche Campus, Campeche, Mexico. \\ Email: ${ }^{*}$ mita@ciatej.mx
}

Received November $8^{\text {th }}, 2013$; revised December $13^{\text {th }}, 2013$; accepted January $9^{\text {th }}, 2014$

Copyright (C) 2014 Khandual Sanghamitra et al. This is an open access article distributed under the Creative Commons Attribution License, which permits unrestricted use, distribution, and reproduction in any medium, provided the original work is properly cited. In accordance of the Creative Commons Attribution License all Copyrights (C) 2014 are reserved for SCIRP and the owner of the intellectual property Khandual Sanghamitra et al. All Copyright (C 2014 are guarded by low and by SCIRP as a guardian.

\begin{abstract}
Jatropha curcas brings attention across the developing world for biodiesel production since it grows in tropical and subtropical climates with no other competing food uses. This crop is gaining popularity in Mexico for biofuel production. Currently, there are not many reports on the native varieties and their yield to estimate the feasibility of the particular genetic resource to use it as an economic crop. So in this part of work an agronomical evaluation of yield, oil content, fatty acid types and biodiesel conversion from the two native varieties of Jatropha curcas from Mexico were compared while being produced in the same agro-climatic condition. The varieties used were based on the phorbol ester content like toxic and nontoxic varieties collected from Yucatan and Veracruz. It was found that the oil content in the seeds of toxic variety was $\mathbf{5 7 \%}$ and oil content of the nontoxic variety was $54 \%$ and also the seed yield is higher. The fatty acid content also varies among the two varieties like $21 \%$ and $23 \%$ in toxic and nontoxic varieties respectively. Again in the nontoxic variety the content of monosaturated fatty acid was higher, which suggests that better quality biodiesel may be expected from this genotype. Transestrification of the two kinds of oil was done using $\mathrm{KOH}$ as a catalyst, but no significant difference was observed in the conversion of biodiesel among the two types of oil from the two genotypes.
\end{abstract}

\section{KEYWORDS}

Biodiesel; Toxic; Biofuel; Transesterification

\section{Introduction}

Vegetable oil is a good option since it can be produced easily in rural areas, where there is an acute need for modern forms of energy and a sustainable way to produce renewable energy. Several vegetable oils, including palm oil, soybean oil, sunflower oil, rapeseed oil, and canola oil have been used to produce biodiesel fuel and lubricants. Hence, in recent years there have been several studies going on using vegetable oils as a fuel in engines as biodiesel $[1,2]$. The suitability and sufficiency of less expensive raw material will be a crucial determinant de-

${ }^{*}$ Corresponding author. livering a competitive biodiesel to satisfy growing demands of ecofriendly products. Fortunately, inedible vegetable oils, mostly produced by seed-bearing trees and shrubs can provide an alternative. Jatropha curcas turns attention across the developing world for biodiesel production as it grows in tropical and subtropical climates without competing food crops [3]. Currently this crop is very popular in Mexico for biofuel production. The Secretary for Agriculture announced in December 2007 that by the end of 2012 Mexico will dedicate approximately 300,000 hectares to the cultivation of crops for biofuel production.

Jatropha curcas, under the Euphorboiaceae family 
originated from Mesoamerica [4] and has a wide geographical distribution in North-America, particularly in Mexico [5]. Two different native varieties of Jatropha curcas available in Mexico are used in this research: one has a low phorbol ester level (non-toxic) and is collected from Veracruz and the other has a high phorbol ester level (toxic) and is collected from Merida, Yucatan [6,7]. Their production, oil content and different fatty acid levels were compared after establishment in same agroclimatic conditions of Campeche State in Mexico. There is very little or no comparative production data available to access native genetic resources of Jatropha curcas in Mexico. This is a comparative study among two varieties of Jatropha curcas to evaluate any morphological difference, production and oil quality grown under the same agroclimatic condition. This is very important for quality biodiesel production and the selection of better genetic material for use.

\section{Materials and Method}

\subsection{Plant Material Collection and Germination}

One toxic variety $(\mathrm{V}-1)$ of seeds was collected from the Chemistry Department, University of Yucatan, and Merida. Its phorbol ester content was higher as reported before. Another non-toxic variety was collected from Veracruz, from The College of Postgraduates, Campus Veracruz. The seeds were germinated in polyethylene bags filled up with 1:1:1 vermiculite: soil: sand as previously prepared. It was kept for two-three months in a greenhouse to avoid heavy rain during the rainy season.

\subsection{Establishment in Campus}

3 months of plantlets were then transferred to the field prepared before. Spacing between plants was $1.5 \times 1.5$ $\mathrm{mts}$. The plants were irrigated twice a week initially and then once a week thereafter without any fertilizer application. When the plants grew in height, it was streamed to keep the height in control at $1.5 \mathrm{mt}$ before the period of flowering.

\subsection{Evaluation of Growth and Production}

Growth was measured mostly by the number of stems/ plant and the production by number of inflorescence/ plant, number of fruits/plants, fruit weight, seed weight or oil content etc.

\subsection{Oil Extraction}

The seed kernels were ground, using a mechanical grinder, and defatted in asoxhlet apparatus, using hexane (boiling point of $40^{\circ} \mathrm{C}-60^{\circ} \mathrm{C}$ ). The extracted lipid was obtained by filtrating the solvent lipid contained to get rid of the lid from the solvent before the hexane was removed using a rotary evaporator apparatus at $40^{\circ} \mathrm{C}$. Extracted seed oil was stored for subsequent physicochemical analysis.

\subsection{Fatty Acid Analysis}

The fatty acid composition of the seed oil was determined using gas chromatography (GC) equipped with a flame ionization detector and a capillary column. Oil was converted to methyl ester using $\mathrm{NaOMe}(1 \mathrm{M})$ in a hexane before being injected into the GC. The identification of the peaks Characteristic and Composition of Jatropha curcas oil seed was achieved by retention times by means of comparing them with authentic standards analyzed under the same conditions [8].

\subsection{Transesterification of Oil for Biodiesel Production}

$0.25 \mathrm{~g} \mathrm{NaoH}$ was mixed well with $24 \mathrm{ml}$ methanol and stirred properly for 20 minutes with a magnetic stirrer. Jatropha oil had taken in conical flax and was previously heated to $60^{\circ} \mathrm{C}$, then mixed well to the above sodium methoxide slowly with a shaker at $300 \mathrm{rpm}$ for $3-6 \mathrm{hrs}$. It was left for 16 - 24 hours for setting. Glycerin settled down in the bottom layer as a thicker layer and the upper layer separated, dried in the air and quantified for biodiesel production.

\section{Results and Discussion}

\subsection{Growth}

It is reported that Jatropha grows in well-drained soils with good aeration and is well adapted to marginal sandy soils with low nutrient content [9]. Ability to grow in alkaline soils has been widely reported, $\mathrm{pH}$ within 6.0 to 8.0/8.5 [10]. The soil analysis of the experimental field was done to find out the soil condition and nutrient availability for the crop. The experimental field soil had a $\mathrm{pH}-6.8$ value and demonstrated some other nutritional values (Table 1), thus the soil condition was not that poor. There was no fertilizer application. The irrigation was initially two times per week where as only once a week thereafter. During the summer the Campeche climate is very hot with temperatures ranging between $35^{\circ} \mathrm{C}$ $-42^{\circ} \mathrm{C}$. The plants continued to look fresh in comparison to the soil which looked very dry (Figure 1).

Crop density and the species are two factors that determine a better yield. Spacing decisions should be based on the environment; things to consider are how it affects competition among trees for water, light and nutrients. Normal spacing for Jatropha is $2.5 \mathrm{mt}$. In our field spacing was $1.5 \mathrm{~m} \times 1.5 \mathrm{~m}$ (Figures 2 and 3 ) as it was 


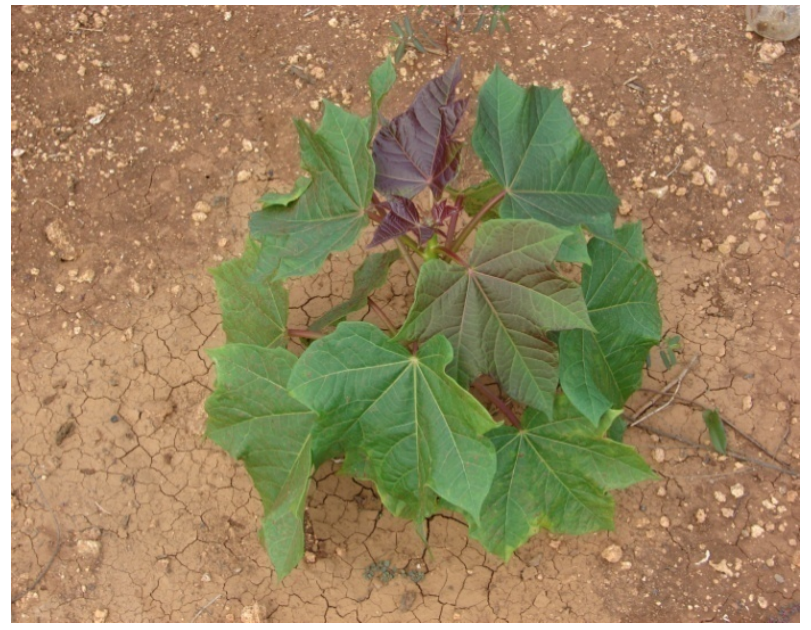

Figure 1. Jatropha plants in dry season, COLPOS, Campeche Campus.

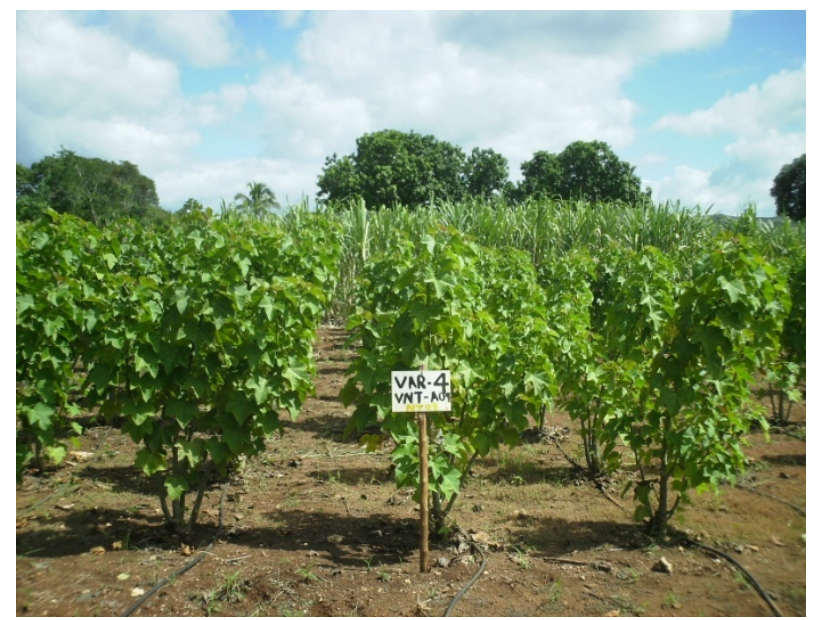

Figure 2. Jatropha plants v-4 in growth, COLPOS, Campeche Campus.

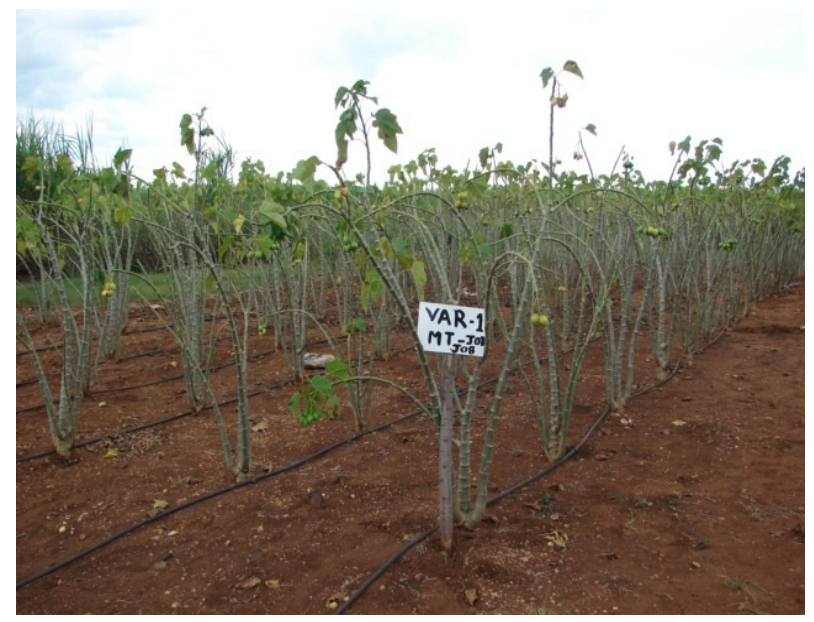

Figure 3. Jatropha plants v-1 in production, COLPOS, Campeche Campus.
Table 1. Nutrient level of experimental soil of Campeche Campus.

\begin{tabular}{cc}
\hline Nnutrients & Unity (ppm) \\
\hline phosphorus & 21,400 \\
Potassium & 26,600 \\
Calcium & 309,000 \\
Magnesium & 42,500 \\
Sodium & $<1000$ \\
Iron & 435,000 \\
Cadmium & $<025$ \\
Mercury & $<01$ \\
Zink & 333 \\
Nitrogen Total & 083 (\% in wt.) \\
\hline
\end{tabular}

irrigated regularly. It was seen that much space is regular that it may not affect the yield for the first two to five years for nutrient competition etc, although in the long term the yield should be evaluated for proper information. Fertilizers could also be used to enhance the crop yield. keeping in mind that sometimes better crop density also gives good results for yield under better supervision and crop maintenance in perennial crops, Jatropha may be managed in that way to get better yields in our experimental field also. The plants were very healthy and did not show any signs of disease.

\subsection{Yield and Oil Content}

It was observed in toxic variety (v-1) the number of branches, inflorescence, number of fruits were more than non-toxic variety. The weight of 100 fruits was more in non-toxic variety due to bigger size of the fruits during 2nd year of production (Table 2, Figures 4 and 5). Seed weight also was more in case of nontoxic variety. Kernel weight and oil content was also little more in toxic variety showing more economical benefits. Oil content was more by $3 \%$ in toxic variety. The fatty acid content was however more in nontoxic variety (Figure 4) was. Although there was no much morphological difference among the plants and fruits, the only difference observed was more rounded fruits in nontoxic variety than the toxic ones. The seeds were quite similar in shape and size.

\subsection{Fatty Acid Analysis}

Natural oils and fats are triglycerides. Oil is a mixture of $96 \%$ to $98 \%$ tri-acylglycerols, which are also known as triglycerides, and esters of fatty acids with Glycerol (glycerin). Serveral fatty acids can be attached to one 


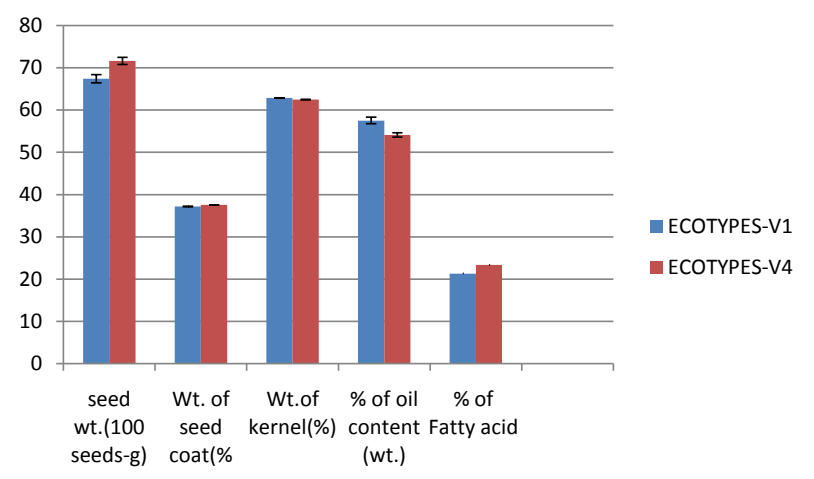

Figure 4. Yield and oil content of two Jatropha curcas variety in COLPOS, Campeche Campus.

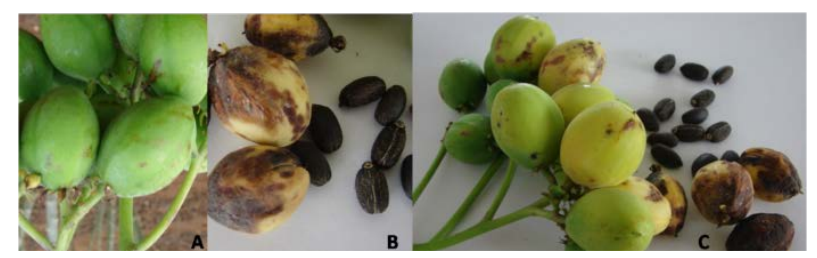

Figure 5. Fruits and seeds of Jatropha curcasin COLPOS, Campeche Campus. Figure (A) and (B) represents the nontoxic variety $\mathrm{V}-4$ and figure $(B)$ represents the toxic variety V-1.

Table 2. Yield of two Jatropha curcas variety in COLPOS, Campeche Campus.

\begin{tabular}{ccccc}
\hline Ecotype & $\begin{array}{c}\text { Number of } \\
\text { branches }\end{array}$ & $\begin{array}{c}\text { No. of } \\
\text { inflorences }\end{array}$ & No. of fruits & $\begin{array}{c}\text { Wt. of 100 } \\
\text { fruits (g) }\end{array}$ \\
\hline $\mathbf{v}-\mathbf{1}$ & $5.2 \pm 0.96$ & $11.83 \pm 3.96$ & $43.4 \pm 14.86$ & $1250 \pm 1.02$ \\
$\mathbf{v}-\mathbf{4}$ & $4.96 \pm 1.2$ & $9 \pm 3.07$ & $34.5 \pm 9.53$ & $1325 \pm 1.05$ \\
\hline
\end{tabular}

glycerol backbone. From triglycerides, biodiesel or fatty acid alcohol esters can be produced in a process called Transesterification. Fatty Acids and glycerin are the building blocks of tri-glycerides. They generally contain 4 to 22 carbon atoms long. For the purposes of discussing biodiesel, the fatty acids are usually 16 and 18 carbons long with between 0 to 3 double bonds. The Palmitic and Stearic Acids are saturated fatty acids that have no double bonds. In biodiesel, they would influence a higher pour point temperature compared to the monounsaturated and poly-unsaturated fatty acids. Biodiesel tends to take on a similar physical viscosity depending on the feedstock it was made from. Therefore, the biodiesel from highly saturated animal fats and greases, which are solid at room temperature, will have cloud points that would make them unsuitable as a fuel in cold weather. Therefore, the desired character in oil for biodiesel production is unsaturated fatty acid as it influences the cold flow property. The oil has more quantities like those of Oleic Acid, Linoleic Acid, or Linolenic Acid as more unsaturated fatty acid content is suitable for quality biodiesel production.

Here we analyzed the types of fatty acids in the two different varieties of Jatropha curcas to predict the future quality of biodiesel. The types of fatty acids analyzed in the two varieties shows quite a difference by their constitution. In case of the toxic variety, Palmitic acid and Linoleic acid were found to have a higher \% whereas in the case of the non-toxic variety Steric acid and Oleic acid were found to have a higher \%.In total the saturated fatty acid wasfound more in thecase of the toxic variety than the non-toxic. Linolenic acid was not found in either of the cases (Table 3, Figure 6, Figures 7(a) and (b)). Therefore, we are expecting more quality biodiesel to come from the non-toxic variety.

\subsection{Transesterification and Biodiesel Yield}

Transesterification done by using $\mathrm{KOH}$ as a catalyst for both typesof Jatropha oil. This does not affect the biodiesel production quantity analyzed volumetrically. In both the cases we found biodiesel obtention was $86 \%$ of the oil and glycerin found $16 \%$. There might be some quality difference in biodiesel due to a fatty acid type difference which has to be analyzed by gas chromatography in further studies. From a commercial point of view both the toxic and non-toxic varieties do not shown any difference in the quantity of biodiesel produced (Figure 8).

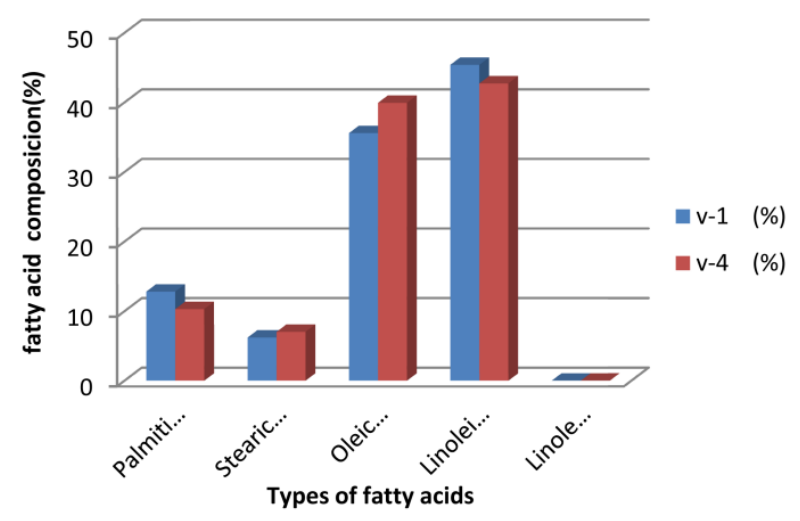

Figure 6. Fatty acid composition of two varieties of Jatropha curcas.

Table 3. Fatty acid composition of two varieties of Jatropha curcas.

\begin{tabular}{ccc}
\hline Fatty acid Types & v-1 (\%) & v-4 (\%) \\
\hline Palmitic acid & 12.80 & 10.28 \\
Stearic acid & 06.20 & 7.02 \\
Oleic acid & 35.58 & 39.94 \\
Linoleic acid & 45.40 & 42.73 \\
Linolenic acid & 00.00 & 0.00 \\
\hline
\end{tabular}




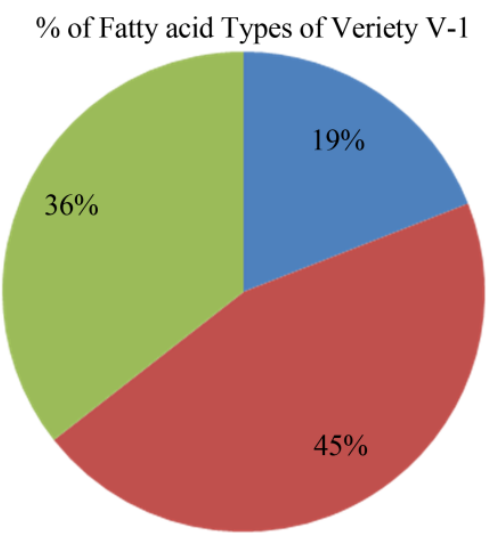

(a)

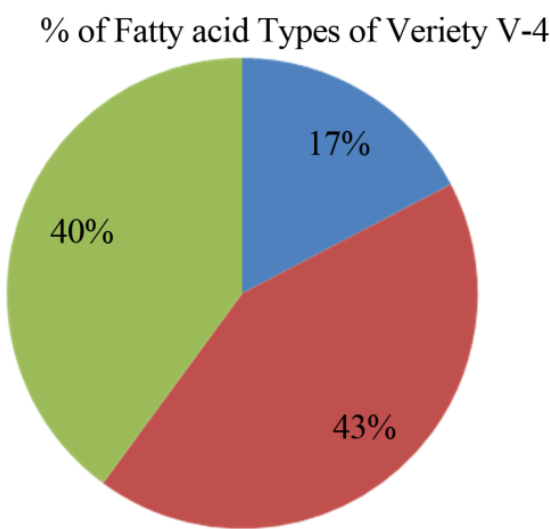

(b)
Saturated fatty acid

Polysaturated fatty acid

- Monosaturated fatty acid

Figure 7. (a) v-1; (b) v-4, Graf of saturated fatty acid, polysaturated fatty acid and monosaturated fatty acid of two varieties of Jatropha curcas.

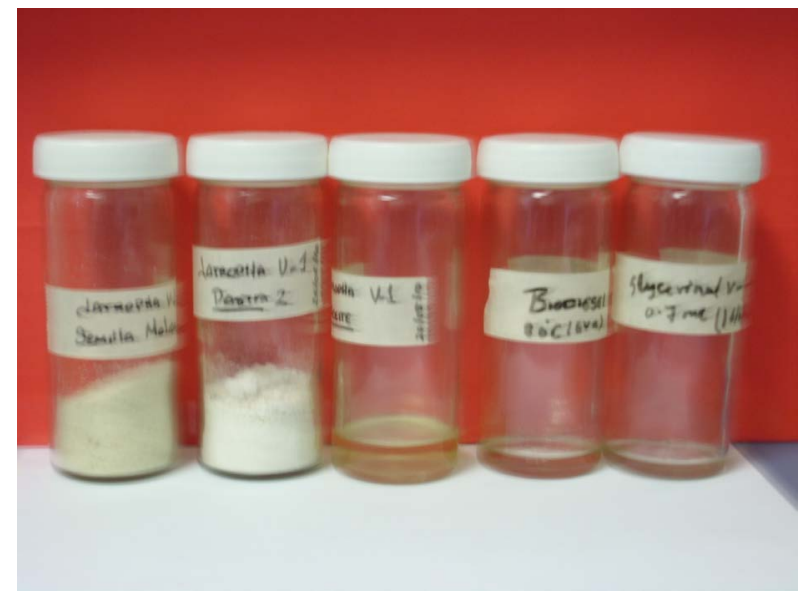

Figure 8. Oil extraction and transesterification Jatropha curcas oil.

\section{Conclusion}

Comparing the two native Jatropha curcas varieties we found that both are good at production level, and that there is not much significant difference. The variety from Yucatan is however better for use in commercial cultivation as the oil content is a bit more. As the fatty acid type is better in non-toxic variety, the quality of Biodiesel is also supposed to be better and after transesterification there is no difference in Biodiesel quantity. So for the environmental security point of view nontoxic variety from Mexico has a great importance in biodiesel production.

\section{REFERENCES}

[1] K. Pramanik, "Properties and Use of Jatropha curcas Oil and Diesel Fuel Blends in Compression Ignition Engine," Renewable Energy, Vol. 28, No. 2, 2003, pp. 239-248.

[2] K. Bozbas, "Biodiesel as an Alternative Motor Fuel: Production and Policies in the European Union,” Renew- able and Sustainable Energy Reviews, Vol. 12, No. 2, 2008, pp. 542-552.

http://dx.doi.org/10.1016/j.rser.2005.06.001

[3] K. Openshaw, "A Review of Jatropha curcas: An Oil Plant of Unfulfilled Promise,” Biomass and Bioenergy, Vol. 19, No. 1, 2000, pp. 1-15.

[4] J. Martínez-Herrera, et al., "Chemical Composition, Toxic/Antimetabolic Constituents, and Effects of Different Treatments on Their Levels, in Four Provenances of $\mathrm{Ja}$ tropha curcas L. from Mexico," Food Chemistry, Vol. 96, No. 1, 2006, pp. 80-89. http://dx.doi.org/10.1016/j.foodchem.2005.01.059

[5] R. K. Henning, “Understanding the Jatropha System,” In: International Consultation on Pro-Poor Jatropha Development, IFAD, Rome, 10-11 April 2008. http://www.ifad.org/events/jatropha/

[6] H. P. S. Makkar and K. Becker, "Jatropha curcas Toxicity: Identification of Toxic Principles,” In: Proceedings of the 5th International Symposium on Poisonous Plants, San Angelo, 19-23 May 1997.

[7] H. P. S. Makkar, et al., "Comparative Evaluation of NonToxic and Toxic Varieties of Jatropha curcas for Chemical Composition, Digestibility, Protein Degradability and Toxic Factors,” Food Chemistry, Vol. 62, No. 2, 1998, pp. 207-215.

http://dx.doi.org/10.1016/S0308-8146(97)00183-0

[8] AOAC, "Official Methods of Analysis," 15th Edition, Association of Official Analytical Chemists, Arlington, 1990.

[9] V. K. Gour, "Production Practices Including Post-Harvest Management of Jatropha curcas,” In: B. Singh, R. Swaminathan and V. Ponraj, Eds., Proceedings of the Biodiesel Conference toward Energy Independence-Focus of Jatropha, Hyderabad, 9-10 June 2006, pp. 223-251.

[10] FACT, "Position Paper on Jatropha curcas L. State of the Art, Small and Large Scale Project Development," Fuels from Agriculture in Communal Technology, 2007. http://www.fact-fuels.org 